\title{
Abundance, composition and natural infection of Anopheles mosquitoes from two malaria-endemic regions of Colombia
}

\author{
Carolina Montoya, Priscila Bascuñán, Julián Rodríguez-Zabala, Margarita M. Correa \\ Grupo de Microbiología Molecular, Escuela de Microbiología, Universidad de Antioquia, Medellín, Colombia
}

\begin{abstract}
Introduction: In Colombia there are three Anopheles species implicated in malaria transmission as primary vectors; however, the local role of some Anopheles species must still be defined.

Objective: To determine the abundance, composition and natural infection rates for Anopheles mosquitoes with Plasmodium spp. in two malaria-endemic regions of Colombia.

Materials and methods: Anopheles mosquitoes were collected using the human-landing catches and while resting in livestock corrals in nine localities of two malaria-endemic regions of Colombia. Mosquitoes were morphologically identified and confirmed by PCR-RFLP-ITS2. Identified mosquitoes were processed and tested for Plasmodium parasite infection by ELISA and ssrRNA-based nested PCR.

Results: We collected 1,963 Anopheles mosquitoes corresponding to nine species. The most abundant species were Anopheles nuneztovari (53.5\%) and A. darlingi (34.5\%), followed by $A$. triannulatus s.l. $(6 \%)$, and other species $(\approx 5.9 \%)$. Three species were naturally infected with Plasmodium spp.: $A$. darlingi, $A$. nuneztovari and $A$. triannulatus s.l.

Conclusions: Natural infection of $A$. darlingi and $A$. nuneztovari indicate that these malaria vectors continue to be effective carriers of Plasmodium in the localities under study in Valle del Cauca and Chocó. Additionally, the infected $A$. triannulatus s.l. collected in livestock corrals in the locality of the department of Córdoba suggests the need for further studies to define the epidemiological importance of this species given its abundance and opportunistic anthropophilic behavior.
\end{abstract}

Key words: Anopheles; Plasmodium; malaria; infection; disease vectors; Colombia. doi: https://doi.org/10.7705/biomedica.v34i2.3553

\section{Abundancia, composición e infección natural de mosquitos Anopheles en dos regiones endémicas para malaria en Colombia}

Introducción. En Colombia hay tres especies de mosquitos Anopheles implicadas como vectores primarios en la transmisión de la malaria o paludismo; sin embargo, el rol local de algunas especies de Anopheles aún debe determinarse.

Objetivo. Determinar la abundancia, la composición y la infección natural de mosquitos anofelinos con Plasmodium spp. en dos regiones endémicas de malaria en Colombia.

Materiales y métodos. Se recolectaron mosquitos del género Anopheles usando los métodos de recolección con cebo humano y en reposo en corrales de ganado vacuno, en nueve localidades de dos regiones endémicas para malaria en Colombia. Los especímenes se identificaron morfológicamente y se confirmaron por reacción en cadena de la polimerasa (PCR) de los polimorfismos en la longitud de los fragmentos de restricción (Restriction Fragment Length Polymorphism, RFLP) en el espaciador intergénico ribosómico nuclear 2 (Internal Transcribed Spacer, ITS-2) (PCR-RFLPITS2). Los especímenes se procesaron y analizaron mediante ELISA y PCR anidada basada en la subunidad pequeña del ARN ribosómico (small subunit ribosomal RNA, ssrRNA) para determinar la infección por Plasmodium.

Resultados. Se recolectaron 1.963 mosquitos Anopheles correspondientes a nueve especies. Anopheles nuneztovari fue la especie predominante $(53,5 \%)$, seguida por $A$. darlingi $(34,5 \%)$, A. triannulatus s.l. $(6 \%)$ y por otras especies $(\approx 5,9 \%)$. Tres especies se encontraron naturalmente infectadas con Plasmodium spp.: A. darlingi, A. nuneztovari y A. triannulatus s.l.

Conclusiones. La infección natural de $A$. darlingi y A. nuneztovari indica que estos vectores primarios siguen siendo actores principales en la transmisión de malaria en las localidades estudiadas de los departamentos del Valle del Cauca y Chocó. Además, el espécimen A. triannulatus s.l. infectado,

\footnotetext{
Author's contributions:

Carolina Montoya and Julián Rodriguez-Zabala processed the samples.

Margarita M. Correa designed the study.

All authors participated in the analysis and interpretation of the data, and the writing of the paper.
} 
recolectado en corrales de animales de la localidad estudiada en el departamento de Córdoba, indica que existe la necesidad de estudios futuros para establecer la importancia epidemiológica de esta especie dada su abundancia y comportamiento antropofílico oportunista.

Palabras clave: Anopheles; Plasmodium; malaria, paludismo; infección; vectores de enfermedades; Colombia. doi: https://doi.org/10.7705/biomedica.v34i2.3553

Malaria continues to be an important world public health problem with an estimate of 438,000 deaths registered during 2015 in tropical and subtropical regions where climate conditions are appropriate for the development of the malaria parasite and its mosquito vector (1).

In Colombia, more than 50,000 new cases were confirmed for malaria in 2015, with approximately $78 \%$ of the cases occurring in the departments of Chocó and Nariño, in the Pacific Coast (PAC), and in Antioquia and Córdoba, in the Urabá BajoCauca and Alto-Sinú (UCS) regions (2). All cases were caused by Plasmodium falciparum (51.8\%) and Plasmodium vivax (46.6\%), while a small percentage corresponded to mixed malaria (1.6\%) (2).

Moreover, the country harbors approximately 47 Anopheles species reported until now $(3,4)$; based on entomological and epidemiological data, three of them have been recognized as primary malaria vectors: Anopheles albimanus, $A$. darlingi and $A$. nuneztovari $(3,5-7)$. Other species have been incriminated as secondary or local vectors, among them, A. pseudopunctipennis, A. punctimacula, A. neivai, A. rangeli, $A$. oswaldoi $(8,9)$. Likewise, recent studies carried out in some malaria-endemic regions of Colombia have shown additional Anopheles species naturally infected with Plasmodium spp., such as $A$. benarrochi $\mathrm{B}$, which was found infected with the two strains of $P$. vivax (8); $A$. triannulatus s.l. and $A$. calderoni with $P$. vivax and $P$. falciparum (9-12), suggesting a possible role of these anopheline mosquitoes in the transmission of the malaria parasite.

However, the implication of these species as malaria vectors is not yet well understood in Colombia, and more evidence is needed to incriminate them in transmission. In addition, permanent changes in environmental and climatic conditions in malaria endemic areas $(6,12)$ highlight the importance of

\footnotetext{
Corresponding author:

Margarita M. Correa, Grupo de Microbiología Molecular, Escuela de Microbiología, Universidad de Antioquia, Medellín, Colombia Teléfono: (574) 2198489

margaritcorrea@gmail.com y mmaria.correa@udea.edu.co

Received: 08/08/16; accepted: 11/07/17
}

frequently monitoring parameters such as abundance, composition and natural infection of the Anopheles species, which would contribute to improving local vector control strategies.

The aim of this study was to determine the abundance, composition and natural infection rates with Plasmodium spp. of Anopheles mosquitoes in two malaria-endemic regions of Colombia.

\section{Materials and methods}

\section{Study area}

Anopheles mosquitoes were collected in nine locations of five municipalities in the Urabá BajoCauca Alto-Sinú (UCS) and Pacific (PAC) regions of Colombia, selected for being endemic for malaria: Tuis Tuis in Tierralta (TA), municipality located in the south of the department of Córdoba, in the Alto Sinú subregion, and characterized by its humid tropical forest (13); El Rayo and Santa Clara, Tarazá (TAZ), located in the northwest of the department of Antioquia in the Bajo Cauca subregion, characterized by dry tropical forest (13); in the PAC region, characterized by humid tropical forest (14), we sampled El Arenal and Doña Josefa municipalities in Atrato (ATR) and San Francisco de Tauchigadó and Puné in Medio Atrato (MAT), Chocó, as well as Córdoba and Zacarías in Buenaventura (BUE), department of Valle del Cauca (figure 1). Localities were selected based on official reports of malaria cases and the geographic distribution of malaria vectors $(15,16)$.

\section{Mosquito collection and sample processing}

Female adult mosquitoes were collected in March and May, 2015, during three days per location, except in Tuis Tuis where we sampled for four days, during six hours daily (18:00-24:00 h). Mosquitoes were captured using human-landing catches (HLC) and while resting in livestock corrals (LC) when available.

Informed consent forms were signed using the protocol for collection procedures approved by the Institutional Review Board of Antioquia University as stated in Minutes 063 of the Comité de Bioética de la Facultad Nacional de Salud Pública. 


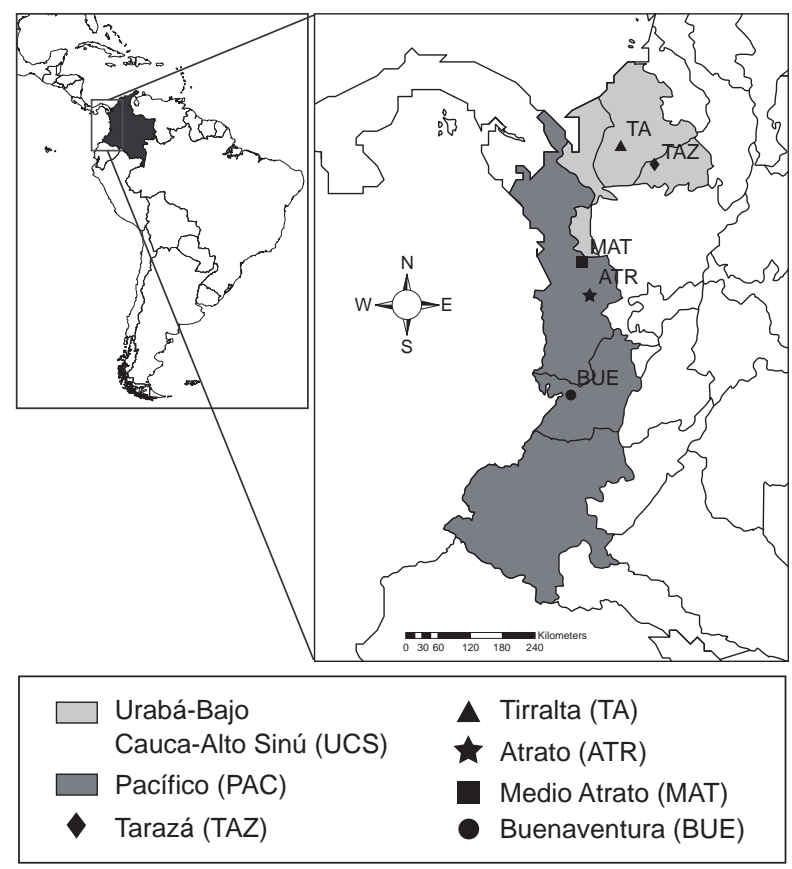

Figure 1. Collection sites. Adult mosquitoes were collected in nine localities of five municipalities of two endemic regions of Colombia: Tarazá (TAZ), department of Antioquia; Tierralta (TA), department of Córdoba; Medio Atrato (MAT) and Atrato (ATR), department of Chocó, and Buenaventura (BUE), department of Valle del Cauca.

\section{Anopheles species identification and preservation}

Collected mosquitoes were identified by morphological features using existing taxonomy keys (3). All the specimens that were difficult to identify morphologically, either because specimens were damaged during collection or because they are part of species complexes or sibling species, as well as less represented species, were confirmed by a PCR-RFLP assay based on the ITS2 sequences $(17,18)$.

Following identification, heads and thoraces were preserved in silica gel for further testing with ELISA; abdomens were stored in $95 \%$ ethanol for DNA extraction and ssrRNA nested PCR. A wing and posterior leg of $5 \%$ of the total adult specimens of each identified species were mounted on glass slides for morphological backup.

\section{Plasmodium detection by ELISA}

We conducted an enzyme-linked immune-sorbent assay (ELISA) for Plasmodium detection following standardized protocols $(15,16)$. Monoclonal antibodies (MAb) were provided by the Centers for Disease Control and Prevention (CDC, Atlanta) (19-22).
The ELISA was conducted using species-specific MAbs in separate plates to detect circumsporozoite (CSP) protein specific for either $P$. falciparum or $P$. vivax (VK210 or VK247 variants). Male Anopheles lysates served as negative controls. In order to detect malaria parasite infection, a preliminary screening test with five heads and thoraces of the same Anopheles species were pooled together and tested in single wells $(6,16)$. Positive pools were confirmed by a second ELISA test in order to reduce chances of reporting false positives.

\section{Plasmodium detection by nested PCR}

A nested PCR was performed to detect infected Anopheles mosquitoes and to confirm ELISA results. Genus-specific primers designed to amplify the small ribosomal DNA subunit (ssrRNA) gene of Plasmodium were used following a previously described protocol (23). DNA from individual abdomens was obtained following a DNA extraction based on salt precipitation procedures as previously described (24); $4 \mu \mathrm{l}$ of extracted DNA were used as template in a $25 \mu \mathrm{l}$ reaction mix for both first and second amplifications of the nested PCR. Plasmodium vivax DNA served as positive control. Finally, PCR products were analyzed on $1 \%$ agarose gels stained with ethidium bromide and photodocumented (ChemiDoc-It 2 Imager System ${ }^{\circledR}$, UVP, LLC, Upland, CA).

\section{Data analysis}

The species abundance was calculated considering the total number of mosquitoes collected in each municipality expressed in percentages. Mosquito infection rates (IR) or the percentage of Plasmodiuminfected Anopheles were assessed by the number of positive Anopheles specimens of a given species (np) out of the total analyzed by municipality (nt) by $100[\mathrm{IR}=(\mathrm{np} / \mathrm{nt}) \times 100]$. Mosquito species mean density, performed for Anopheles species with more than five specimens per locality, was calculated as the geometric mean of the number of mosquitoes captured per person each night. In the case of the collections of resting specimens in livestock corrals, the mean density was expressed as the geometric mean of the number of mosquitoes captured per corral per night.

\section{Results}

\section{Anopheles species composition and abundance}

A total of 1,963 female Anopheles mosquitoes were collected in nine locations from five municipalities in two malaria-endemic regions of Colombia (figure 
1). We collected 155 mosquitoes in TAZ, 287 in TA, 500 in MAT, 242 in ATR and 779 in BUE (table 1). Anopheles nuneztovari was the most abundant species with $53.5 \%$ of the total collected specimens, followed by $A$. darlingi with $34.5 \%$, A. triannulatus s.l. with $6 \%, A$. albitarsis s I. with $4 \%$, and $A$. pseudopunctipennis with $1.4 \%$; other species such as $A$. albimanus, $A$. apicimacula, A. punctimacula and $A$. calderoni were present in low frequencies and together accounted for $0.5 \%$ (table 2 ) of the total.

As regards species composition according to location (table 1), A. nuneztovari was the most abundant species collected in the location of Tuis Tuis (TA), with $62.3 \%$ and a mean density of 2.3 mosquitoes/ person/night, followed by $A$. triannulatus s.I. (15.3\%, 0.3 resting mosquitoes/livestock corral/night) and
A. darlingi (13.2\%, 0.4 mosquitoes/person/night). Other species were present in lower frequencies, including $A$. pseudopunctipennis (8.7\%) and $A$. albimanus (0.3\%).

In the locality of El Rayo (TAZ), the predominant species were $A$. albitarsiss I. with $64.2 \%$ and a mean density of 0.4 mosquitoes/person/night and 1.3 resting mosquitoes/livestock corral/night, and A. triannulatus s.l. with $35.8 \%$ and a mean density of 0.3 mosquitoes/person/night, and 0.8 resting mosquitoes/livestock corral/night. In the locality of Santa Clara (TAZ), the predominant species were A. triannulatus s.l. (58.3\%, 0.4 mosquitoes/person/ night) and $A$. nuneztovari (16.7\%); other species such as $A$. pseudopunctipennis, A. albimanus, $A$. apicimacula were present in lower frequencies.

Table 1. Data on abundance, composition and natural Plasmodium infection in Anopheles mosquitoes

\begin{tabular}{|c|c|c|c|c|c|}
\hline $\begin{array}{l}\text { Department } \\
\text { (Municipality) } \\
\text { Locality/Coordinates }\end{array}$ & $\begin{array}{l}\text { Collection date } \\
\text { (Number of days) }\end{array}$ & Species & n (\%) & $\begin{array}{l}\text { Mean density }{ }^{\star} / \\
\text { recollection } \\
\text { method }\end{array}$ & $\begin{array}{l}\text { Plasmodium } \\
\text { species (IR) }\end{array}$ \\
\hline Córdoba (Tierralta) & \multirow[t]{5}{*}{ March, 2015 (4) } & A. nuneztovari & 179 (62.3) & 2.3 HLC & \\
\hline Tuis Tuis & & A. triannulatus s.I. & 44 (15.3) & 0.3 LC & Plasmodium \\
\hline \multirow[t]{3}{*}{$8^{\circ} 2^{\prime} 34.9^{\prime \prime} \mathrm{N}, 76^{\circ} 5^{\prime} 23.9^{\prime \prime} \mathrm{W}$} & & A. darlingi & 38 (13.2) & 0.4 HLC & spp. $^{a}(2.2 \%)$ \\
\hline & & A. pseudopunctipennis & $25(8.7)$ & 0.4 HLC & \\
\hline & & A. albimanus & $1 \quad(0.3)$ & & \\
\hline Antioquia (Tarazá) & \multirow[t]{4}{*}{ March, 2015 (3) } & A. albitarsis s.l. & $84(64.2)$ & 0.4 HLC & - \\
\hline El Rayo & & & & 1.3 LC & - \\
\hline \multirow[t]{2}{*}{ 7³2'20.5”'N, 75²1'59.1'”W } & & A. triannulatus s.I. & $47(35.8)$ & 0.3 HLC & \\
\hline & & & & 0.8 LC & \\
\hline Santa Clara & \multirow{5}{*}{ March, 2015 (3) } & A. triannulatus s.l. & $14(58.3)$ & 0.4 HLC & - \\
\hline \multirow[t]{4}{*}{ 742'49.7’'N, 75³0’45.2’'W } & & A. nuneztovari & $4(16.6)$ & & - \\
\hline & & A. pseudopunctipennis & $3(12.5)$ & & - \\
\hline & & A. albimanus & $2(8.3)$ & & - \\
\hline & & A. apicimacula & $1(4.1)$ & & - \\
\hline Chocó (Atrato) & \multirow[t]{4}{*}{ March, 2015 (3) } & A. darlingi & $75(50.6)$ & $1.5 \mathrm{HLC}$ & P. falciparum ${ }^{\mathrm{a}, \mathrm{b}}$ \\
\hline Arenal & & A. nuneztovari & $72(48.6)$ & $1.4 \mathrm{HLC}$ & $(1.3 \%)$ \\
\hline \multirow[t]{2}{*}{ 5॰31'45.1'”N, 76³6'57.9'”W } & & A. calderoni & $1(0.7)$ & & HLC/Outdoors \\
\hline & & A. darlingi & 77 (81.9) & 1.7 HLC & - \\
\hline Doña Josefa & \multirow[t]{2}{*}{ March, 2015 (3) } & A. nuneztovari & $14(14.8)$ & 0.2 HLC & - \\
\hline 5॰33'8.2'”N, 76³8'45.8'” & & A. apicimacula & $3(3.1)$ & & - \\
\hline Chocó (Medio Atrato) & \multirow[t]{3}{*}{ March, 2015 (3) } & A. darlingi & $341(99.1)$ & 6.9 HLC & \\
\hline San Francisco de Tauchigadó & & A. triannulatus s.I. & $2(0.6)$ & & \\
\hline $6^{\circ} 5^{\prime} 20^{\prime \prime} \mathrm{N}, 76^{\circ} 43^{\prime} 42.2^{\prime} \mathrm{W}$ & & A. punctimacula & $1(0.3)$ & & \\
\hline Puné & \multirow[t]{3}{*}{ March, 2015 (3) } & A. darlingi & $147(94.2)$ & 3.4 HLC & - \\
\hline 557'57.7'”N, 7643’39'”W & & A. triannulatus s.I. & $6(3.8)$ & & - \\
\hline & & A. nuneztovari & $3(1.9)$ & & - \\
\hline Valle del Cauca (Buenaventura) & \multirow[t]{3}{*}{ May, 2015 (3) } & \multirow[t]{3}{*}{ A. nuneztovari } & \multirow[t]{3}{*}{715 (100) } & \multirow[t]{3}{*}{ 14.2 HLC } & Plasmodium \\
\hline Córdoba & & & & & spp. $^{a}(0.13 \%)$ \\
\hline 358'12.2'”, 7655'47’'W & & & & & HLC/Outdoors \\
\hline Zacarías & \multirow[t]{2}{*}{ May, 2015 (3) } & \multirow[t]{2}{*}{ A. nuneztovari } & \multirow[t]{2}{*}{$64(100)$} & \multirow[t]{2}{*}{$1.7 \mathrm{HLC}$} & - \\
\hline 3॰49'2.3'”, $76^{\circ} 59^{\prime} 43.9^{\prime \prime} \mathrm{W}$ & & & & & \\
\hline
\end{tabular}

IR: Infection rate (number of positive specimens/number of total specimens analyzed) $\times 100$

LC: Resting in livestock corrals; HLC: Human-landing catches

a Plasmodium detection by nested PCR

b Plasmodium detection by ELISA

* Mean density: Geometric mean of the number of mosquitoes/person/night or resting mosquitoes/livestock corral/night, calculated for Anopheles species with $>5$ specimens per locality 
In the location of El Arenal (ATR) the most frequent species was $A$. darlingi with $50.6 \%$ and a mean density of 1.5 mosquitoes/person/night, followed by $A$. nuneztovari (48.6\%, 1.4 mosquitoes/person/ night) and $A$. calderoni (0.7\%).

Similarly, in the location of Doña Josefa (ATR) the most frequent species were $A$. darlingi $(81.9 \%)$ and $A$. nuneztovari $(14.8 \%)$, with a mean density of 1.7 mosquitoes/person/night and 0.2 mosquitoes/person/night, respectively, followed by A. apicimacula with $3.1 \%$. In the location of San Francisco de Tauchigadó (MAT), the predominant species was $A$. darlingi with $99.1 \%$ and 6.9 mosquitoes/person/night; A. triannulatus s.l. and $A$. nuneztovari together represented $0.9 \%$.

Likewise, in the location of Puné (MAT) A. darlingi (94.2\%, 3.4 mosquitoes/person/night) was the predominant species, while $A$. triannulatus s.l. $(3.8 \%)$ and $A$. nuneztovari $(1.9 \%)$ were found in low abundances.
Finally, in the two locations of BUE, Córdoba and Zacarías, $A$. nuneztovari was found as the only species (100\%), with a mean density of 14.2 mosquitoes/person/night and 1.7 mosquitoes/person/ night, respectively.

In general, the two main Colombian vectors, $A$. darlingi and $A$. nuneztovari, were present in most locations of the two regions (PAC and UCS). However, species such as $A$. albitarsis s.l. and $A$. pseudopunctipennis were only detected in UCS and $A$. punctimacula and $A$. calderoni in PAC.

\section{Biting preference}

There were differences in the biting preference of the most abundant species determined by the collection method (HLC or LC) (figure 2). Anopheles nuneztovari and $A$. darlingi mosquitoes were mainly collected by HLC $(99.7 \%$ and $99.8 \%$, respectively). $A$. triannulatus s.l. was mostly captured in LC (66.6\%), while the remaining $33.3 \%$ were collected by HLC.

Table 2. Total Anopheles species abundance in the five municipalities of collection

\begin{tabular}{|c|c|c|c|c|}
\hline Anopheles species & Municipality & $\begin{array}{c}\text { Species } \\
\text { abundance } \\
\%\end{array}$ & $\begin{array}{l}\text { Number of } \\
\text { specimens identified } \\
\text { by morphology }\end{array}$ & $\begin{array}{l}\text { Number of specimens } \\
\text { molecularly confirmed }\end{array}$ \\
\hline A. nuneztovari & $\begin{array}{l}\text { Tarazá,Tierralta, Atrato, Medio } \\
\text { Atrato, Buenaventura }\end{array}$ & 53.5 & 1051 & 113 \\
\hline A. darling & Tarazá, Atrato, Medio Atrato & 34.5 & 677 & 34 \\
\hline A. triannulatus s.l. & Tarazá, Tierralta, Medio Atrato & 6 & 119 & 9 \\
\hline A. albitarsiss.l. & Tarazá & 4 & 79 & 27 \\
\hline A. pseudopunctipennis & Tarazá, Tierralta & 1.4 & 28 & 2 \\
\hline A. albimanus & Tarazá, Tierralta & 0.1 & 3 & 2 \\
\hline A. apicimacula & Atrato & 0.1 & 3 & 1 \\
\hline A. calderoni & Atrato,Tarazá & 0.1 & 2 & - \\
\hline A. punctimacula & Medio Atrato & $<0.01$ & 1 & 1 \\
\hline
\end{tabular}

* By PCR-RFLP-ITS2

A. nuneztovari

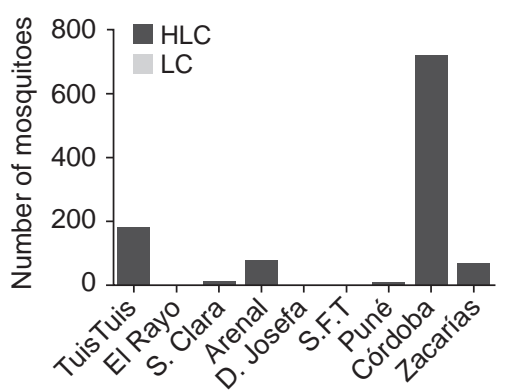

A. darlingi

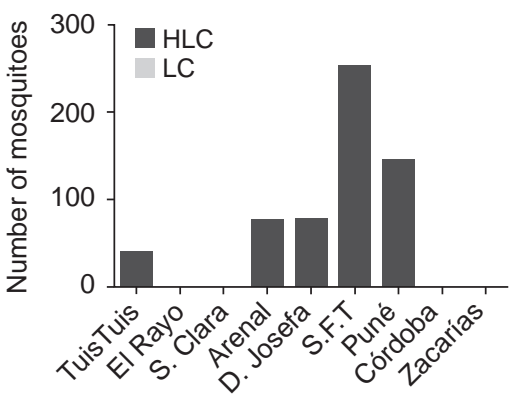

A. triannulatus

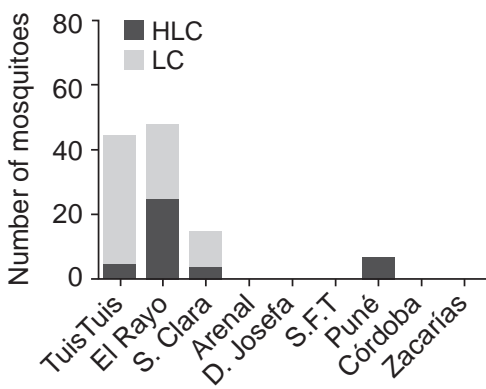

Figure 2. Biting preference of the three most abundant species. Mosquitoes were collected in nine localities of five municipalities of two malaria endemic regions of Colombia. Córdoba: Tuis Tuis; Antioquia: El Rayo and S. Clara (Santa Clara); Chocó: Arenal (El Arenal), D. Josefa (Doña Josefa), S.F.T (San Francisco de Taunchigadó) and Puné; Valle del Cauca: Córdoba and Zacarías. Bars represent the number of mosquitoes collected either by human-landing catches (HLC) or in livestock corrals (LC), showing human or animal biting preference, respectively. 
Detection of natural Plasmodium infection in Anopheles spp.

In order to assess the natural infection rates of Anopheles mosquitoes with Plasmodium spp.in the nine municipalities under study, 1,914 specimens were first analyzed by ELISA. This allowed for the detection of one $A$. darlingi mosquito infected with $P$. falciparum in El Arenal (ATR). The result was confirmed by a second ELISA and a nested $P C R$, which were both positive. An infection rate (IR) of $1.3 \%$ was calculated for this species when comparing with the total amount of $A$. darlingi specimens analyzed in ATR. Furthermore, 1,142 specimens were examined by nested PCR in order to detect infection with Plasmodium spp., which allowed for the detection of two additional positive samples: one $A$. triannulatus s.l. specimen collected in the location of Tuis Tuis (TA), with an IR of $2.2 \%$ for this location, and the second, an $A$. nuneztovari specimen collected in the location of Córdoba (BUE), representing an IR of $0.13 \%$.

\section{Discussion}

Abundance and the preference to bite humans are among the characteristics that define a mosquito species as an effective human vector (25). However, species composition and frequencies vary among sampling sites and seasons, rendering constant monitoring of these parameters essential $(7,12)$. In this study we analyzed species abundance and composition, biting preferences and natural infection with Plasmodium of Anopheles mosquitoes from nine locations of two malaria-endemic regions of Colombia. Results showed a predominance of A. nuneztovari mosquitoes (53.5\%), followed by A. darlingi (34.5\%), known as the main malaria vectors in the country $(5-7,16)$. In seven of the nine locations sampled during March and May, 2015, A. nuneztovari mosquitoes were present except in El Rayo-TAZ (Antioquia) and San Francisco de Tauchigadó-MAT (Chocó). Similarly, other studies have found $A$. nuneztovari in some locations of Antioquia and Chocó $(6,7,11,16,26)$. Interestingly, the last report of $A$. nuneztovari in Chocó dates from 2004 (26), which evidences the importance of continuously listing malaria vectors present in the different regions of Colombia and keeping updated information for vector control strategies. In addition, these two species showed a high preference to bite humans in most of the sampled locations, with very few specimens collected in livestock corrals (figure 2). Besides, the natural infection of $A$. nuneztovari and $A$. darlingi with the Plasmodium parasite, together with the data showing that both species presented the highest mean mosquito densities (up to 14.2 mosquitoes/person/night and 6.9 mosquitoes/person/night, respectively), are two important results that reinforce reports on their highly anthropophilic feeding habits and their role as primary malaria vectors $(5-7,16)$.

It is worth noting that three $A$. albimanus specimens were collected in TA, Córdoba and TAZ, Antioquia, which are two non-coastal locations. These low frequencies were expected given the ecological characteristics of the locations sampled, as $A$. albimanus is predominantly found at lower altitudes and on coastal areas, preferring slightly brackish larval habitats $(5,15)$. However, some authors have shown the presence of $A$. albimanus in higher altitudes and non-costal localities $(27,28)$, which suggests adaptability of this species to other ecosystems. Although no Plasmodium-infected $A$. albimanus was found in this study, this vector might be contributing to the malaria epidemiology in these locations. Therefore, the need to understand the role of this species in higher and non-coastal regions demand more studies to continue monitoring $A$. albimanus in these areas.

Moreover, in this study no A. albimanus specimens were found in the location of Zacarías where other studies had previously reported this species (29). This might be a consequence of the temporal differences between both studies and even of differences in collection seasonality, as the cited study sampled mosquitoes between August and September, 1993, and December and January, 1994, while mosquitoes in our study were collected in May, 2015.

Furthermore, $A$. triannulatus s.l. was the third most abundant species in this inventory; it was found in the department of Antioquia, as formerly documented $(6,16)$, and it was the predominant species in the location of Santa Clara (TAZ). Likewise, $A$. triannulatus s.l. abundance in the municipality of Tierralta, Córdoba, was marginally higher than the abundance reported for $A$. darlingi. This result agrees with a previous study conducted in 20082009, where $A$. triannulatus s.l. was the second most abundant species in the same municipality, but in a different location (6), and a study in the department of Córdoba where $A$. triannulatus s.l. and $A$. nuneztovari larvae were predominant (30). Additionally, most of the specimens were collected in livestock corrals (figure 2), which suggests a zoophilic biting preference, as formerly reported (5). 
The abundance of this species might be influenced by livestock production, one of the main economic activities in this department (6). However, one third (33.3\%, figure 2) of the specimens were collected by HLC. Moreover, a Plasmodium-infected specimen was collected in Tierralta, Córdoba, as previously reported for another location of this municipality (31).

These results indicate that $A$. triannulatus s.l. might be contributing to malaria transmission in regions where this species is present $(6,11,12)$. However, as the infected specimen on this study was recollected in livestock corrals and the Plasmodium spp. infection was only PCR-detected in the midgut of the mosquito, no transmission to humans can be inferred from this data as formerly discussed by other authors (11). Consequently, no incrimination should be stated until this is complemented with epidemiological data.

Other species such as $A$. albitarsis s.I., A. pseudopunctipennis, $A$. apicimacula, $A$. punctimacula and $A$. calderoni were present in either one or two of the nine locations sampled (table 2). Anopheles albitarsis s.l. was the predominant species in the location of El Rayo in TAZ (Antioquia), where no specimens of the species $A$. nuneztovari and $A$. darlingi were present, which is interesting since $A$. albitarsis s.l. is usually detected in low numbers (6).

Overall, these results indicate that the Anopheles species composition in Antioquia, Córdoba, Chocó and Valle del Cauca remain relatively stable with $A$. nuneztovari and $A$. darlingi being the most predominant species and sharing their niche with other Anopheles species. Nonetheless, the important presence of $A$. triannulatus s.l. in the northwestern locations, presenting an opportunistic antropophilic behavior and detected with natural infection, suggests the relevance of conducting further studies to determine its importance in human malaria transmission.

\section{Acknowledgements}

We are grateful to all the members of the Grupo de Microbiología Molecular of Universidad de Antioquia for their assistance in the field and in the laboratory.

\section{Conflicts of interest}

The authors declare no conflicts of interest.

\section{Funding}

This work was carried out in the framework of a project funded by the Departamento Administrativo de Ciencia, Tecnología e Innovación (Colciencias),
No. 596-2013, granted to MMC. Support was also received from Estrategia para la Sostenibilidad de Grupos de Investigación, Universidad de Antioquia 2016-2017, No. ES84160123. PB is a postdoctoral fellow of Colciencias with a grant from Es tiempo de volver 2014 program, code 2015-8423. CM received funding from Colciencias through a grant from the Joven Investigador 2014 program.

\section{References}

1. World Health Organization. World Malaria Report. Geneva: WHO; 2015. Accessed: June 25, 2016. Available from: http://apps.who.int/iris/bitstream/10665/200018/1/9789241 565158_eng.pdf

2. Instituto Nacional de Salud. Comportamiento de los eventos de vigilancia en salud pública. Enfermedades transmitidas por vectores. Malaria. Semana epidemiológica número 52 de 2015 (27 dic. - 02 ene.). Boletín Epidemiológico Semanal. 2015;52. Accessed: March 3, 2017. Available from: http://www.ins.gov.co/boletin-epidemiologico/Boletn\%20 Epidemiolgico/2015\%20Boletin\%20epidemiologico\%20 Semana\%2052.pdf

3. González R, Carrejo N. Introducción al estudio taxonómico de Anopheles de Colombia. Claves y notas de distribución. Segunda edición. Cali: Universidad del Valle; 2009. p. 260.

4. Montoya-Lerma J, Solarte YA, Giraldo-Calderón GI, Quiñones ML, Ruiz-López F, Wilkerson RC, et al. Malaria vector species in Colombia - A review. Mem Inst Oswaldo Cruz. 2011;106(Suppl.1):223-38. https://doi.org/10.1590/ S0074-02762011000900028

5. Olano VA, Brochero HL, Sáenz R, Quiñones ML, Molina JA. Mapas preliminares de la distribución de especies de Anopheles vectores de malaria en Colombia. Biomédica. 2001;21:402-8.

6. Naranjo-Díaz N, Rosero D, Rua-Uribe G, Luckhart S, Correa M. Abundance, behavior and entomological inoculation rates of anthropophilic anophelines from a primary Colombian malaria endemic area. Parasit Vectors. 2013;6:61. https://doi.org/10.1186/1756-3305-6-61

7. Naranjo-Díaz N, Altamiranda M, Luckhart S, Conn JE, Correa MM. Malaria vectors in ecologically heterogeneous localities of the Colombian Pacific region. PLoS One. 2014;9: e103769. https://doi.org/10.1371/journal.pone.0103769

8. Quiñones ML, Ruiz F, Calle DA, Harbach RE, Erazo HF, Linton Y. Incrimination of Anopheles (Nyssorhynchus) rangeli and $A n$. (Nys.) oswaldoias natural vectors of Plasmodium vivax in Southern Colombia. Mem Inst Oswaldo Cruz. 2006;101: 617-23. https://doi.org/10.1590/S0074-02762006000600007

9. Gómez GF, Bickersmith SA, González R, Conn JE, Correa MM. Molecular taxonomy provides new insights into Anopheles species of the Neotropical Arribalzagia series. PLoS One. 2015;10:e0119488. https://doi.org/:10.1371/ journal.pone.0119488

10. Orjuela LI, Herrera M, Erazo H, Quiñones ML. Especies de Anopheles presentes en el departamento del Putumayo y su infección natural con Plasmodium. Biomédica. 2013;33: 42-52. https://doi.org/10.7705/biomedica.v33i1.619

11. Rosero DA, Naranjo-Díaz N, Álvarez N, Cienfuegos AV, Torres C, Luckhart S, et al. Colombian Anopheles 
triannulatus (Diptera: Culicidae) naturally infected with Plasmodium spp. ISRN Parasitol. 2013;2013:927453. https://doi.org/10.5402/2013/927453

12. Orjuela LI, Ahumada ML, Ávila I, Herrera S, Beier JC, Quiñones ML. Human biting activity, spatial-temporal distribution and malaria vector role of Anopheles calderoni in the southwest of Colombia. Malar J. 2015;14:256. https://doi. org/10.1186/s12936-015-0764-6

13. Instituto Geográfico Agustín Codazzi. Atlas de Colombia. Quinta edición. Bogotá: Imprenta Nacional de Colombia; 2002. p. 342.

14. Morrone JJ. Biogeographic areas and transition zones of Latin America and the Caribbean islands based on panbiogeographic and cladistic analyses of the entomofauna. Annu Rev Entomol. 2006;51:467-94. https://doi.org/10.1146/ annurev.ento.50.071803.130447

15. Gutiérrez LA, Naranjo N, Jaramillo LM, Muskus C, Luckhart S, Conn JE, et al. Natural infectivity of Anopheles species from the Pacific and Atlantic Regions of Colombia. Acta Trop. 2008;107:99-105. https://doi.org/10.1016/j. actatropica.2008.04.019

16. Gutiérrez LA, González JJ, Gómez GF, Castro MI, Rosero DA, Luckhart $\mathrm{S}$, et al. Species composition and natural infectivity of anthropophilic Anopheles (Diptera: Culicidae) in the states of Córdoba and Antioquia, Northwestern Colombia. Mem Inst Oswaldo Cruz. 2009;104:1117-24. https://doi.org/10.1590/S0074-02762009000800008

17. Zapata MA, Cienfuegos AV, Quirós OI, Quiñones ML, Luckhart S, Correa MM. Discrimination of seven Anopheles species from San Pedro de Urabá, Antioquia, Colombia by polymerase chain reaction-restriction fragment length polymorphism analysis of ITS sequences. Am J Trop Med Hyg. 2007;77:67-72. https://doi.org/10.4269/ajtmh.2007.77.67

18. Cienfuegos AV, Gómez GF, Córdoba LA, Luckhart S, Conn JE, Correa MM. Diseño y evaluación de metodologías basadas en PCR-RFLP de ITS2 para la identificación molecular de mosquitos Anopheles spp. (Diptera: Culicidae) de la Costa Pacífica de Colombia. Rev Biomed. 2008;19: 35-44.

19. Wirtz RA, Burkot TR, Graves PM, Andre RG. Field evaluation of enzyme-linked immunosorbent assays for Plasmodium falciparum and Plasmodium vivax sporozoites in mosquitoes (Diptera: Culicidae) from Papua New Guinea. J Med Entomol.1987;24:433-7.

20. Wirtz RA, Charoenvit Y, Burkot TR, Esser KM, Beaudoin $\mathbf{R L}$, et al. Evaluation of monoclonal antibodies against Plasmodium vivax sporozoites for ELISA development. Med Vet Entomol. 1991;5:17-22. https://doi.org/10.1111/j.13652915.1991.tb00515.x
21. Wirtz RA, Sattabongkot J, Hall T, Burkot TR, Rosenberg R. Development and evaluation of an enzyme-linked immunosorbent assay for Plasmodium vivax-VK247 sporozoites. J Med Entomol. 1992;29:854-7.

22. Wirtz RA, Zavala F, Charoenvit Y, Campbell GH, Burkot TR, Schneider I, et al. Comparative testing of monoclonal antibodies against Plasmodium falciparum sporozoites for ELISA development. Bull World Health Organ. 1987;65: 39-45.

23. Singh B, Bobogare A, Cox-Singh J, Snounou G, Abdullah MS, Rahman HA. A genus- and species-specific nested polymerase chain reaction malaria detection assay for epidemiologic studies. Am J Trop Med Hyg. 1999;60:687-92.

24. Rosero DA, Gutiérrez LA, Cienfuegos AV, Jaramillo LM, Correa MM. Optimización de un procedimiento de extracción de ADN para mosquitos anofelinos. Rev Colomb Entomol. 2010;36:260-3.

25. Cohuet A, Harris C, Robert V, Fontenille D. Evolutionary forces on Anopheles: What makes a malaria vector? Trends Parasitol. 2010;26:130-6. https://doi.org/10.1016/j.pt.2009. 12.001

26. Sierra DM, Vélez ID, Linton YM. Malaria vector Anopheles (Nyssorhynchus) nuneztovari comprises one genetic species in Colombia based on homogeneity of nuclear ITS2 rDNA. J Med Entomol. 2004;41:302-7. https://doi.org/10.1603/00222585-41.3.302

27. González R, Martínez LM. Nuevo registro de distribución altitudinal de Anopheles albimanus Wiedemann (Diptera: Culicidae). Boletín del Museo de Entomología. 2006;7:19-23.

28. Pinault LL, Hunter FF. New highland distribution records of multiple Anopheles species in the Ecuadorian Andes. Malar J. 2011;10:236. https://doi.org/10.1186/1475-2875-10-236.

29. Olano VA, Carrasquilla G, Méndez F. Transmisión de malaria urbana en Buenaventura, Colombia: aspectos entomológicos. Pan Am. Public Health. 1997;1:287-94. https:// doi.org/10.1590/S1020-49891997000400005

30. Conde M, Pareja P, Orjuela L, Ahumada M, Durán S, Jara JA, et al. Larval habitat characteristics of the main malaria vectors in the most endemic regions of Colombia: Potential implications for larval control. Malar J. 2015;14:476. https:// doi.org/10.1186/s12936-015-1002-y

31. Aycardi-Morinelli MP, Correa-Ochoa MM, Zárate-Peñata EdC, Padrón-Echenique C. Determinación de especies anofelinas en una localidad endémica de malaria en el departamento de Córdoba, noroeste de Colombia. Entomotropica. 2016;31:294-301. 